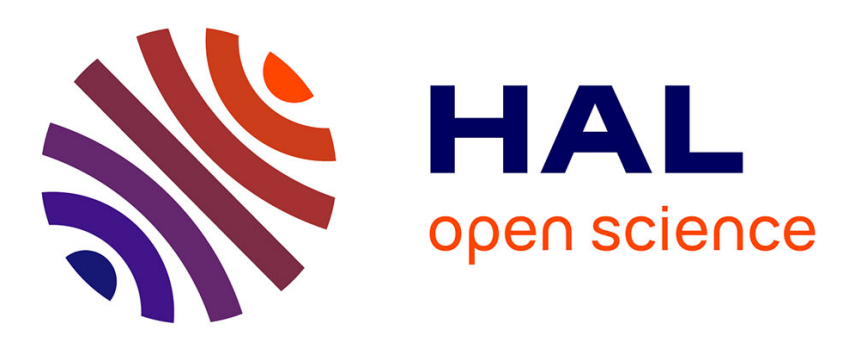

\title{
Effect of seed production area on the seedling resistance of wheat to Fusarium seedling blight
}

Ákos Mesterházy

\section{To cite this version:}

Ákos Mesterházy. Effect of seed production area on the seedling resistance of wheat to Fusarium seedling blight. Agronomie, 1985, 5 (6), pp.491-497. hal-00884776

\section{HAL Id: hal-00884776 \\ https://hal.science/hal-00884776}

Submitted on 1 Jan 1985

HAL is a multi-disciplinary open access archive for the deposit and dissemination of scientific research documents, whether they are published or not. The documents may come from teaching and research institutions in France or abroad, or from public or private research centers.
L'archive ouverte pluridisciplinaire HAL, est destinée au dépôt et à la diffusion de documents scientifiques de niveau recherche, publiés ou non, émanant des établissements d'enseignement et de recherche français ou étrangers, des laboratoires publics ou privés. 


\title{
Effect of seed production area on the seedling resistance of wheat to Fusarium seedling blight
}

\author{
Ákos MESTERHÁZY \\ Cereal Research Institute, Szeged, Hungary
}

SUMMARY

In 1980-1983 the effect of location was studied on the seedling performance of wheat in relation to Fusarium graminearum. In 1980, 90 genotypes from five locations were analyzed, in 198136 varieties from ten, in 1982 36 cultivars from eleven and in 1983 a further 48 from six. There were significant differences in variety resistance. This variety reaction could be reproduced fairly well from year to year, i.e. it has a real genetical background. Highly significant differences were obtained between the average performance of genotypes from different locations. This is important, as only genotypes from the same nursery could really be compared and theoretically, because this shows that environmental effects influence not only the actual crop, but the predisposition of the seedling produced from seeds grown under these conditions, too.

Additional key word : Predisposition.

Entre 1980 et 1983, l'influence du lieu de production sur le comportement des plantules de blé vis-à-vis de Fusarium graminearum a été étudiée. Ont été examinées : en 1980, 90 génotypes issus de 5 lieux de production, en 1981, 36 variétés issues de 10 lieux, en 1982, 36 variétés de 11 lieux et, en 1983, 48 variétés de 6 lieux. La résistance des variétés est différente et peut être bien reproduite d'année en année ; les différences ont donc une réelle base génétique.

Nous avons observé que les parcelles d'un même génotype situées en différents lieux de production présentent, vis-à-vis du comportement moyen du génotype, des différences significatives. C'est important, puisqu'en théorie ce ne sont que des génotypes du même lieu de production qui sont comparables, et aussi parce que l'effet du lieu de production peut influencer non seulement la plante actuelle, mais aussi des plantules obtenues des semences produites dans les mêmes conditions.

Mot clé additionnel : Prédisposition.

\section{INTRODUCTION}

An earlier experiment with three wheat varieties from 15 sites (MESTERHÁZY, 1978a) showed that the seedling reaction to Fusarium graminearum, of samples of the same genotype from different fields, may be very different. As this result allowed only limited conclusions on the resistance and location effects, the need arose to do more research in this field. This is important, because a relationship was found between seedling and head blight reactions of wheat, which was valid for a large part of the materials (MESTERHÁZY, 1983). The correlation was closest where only those varieties were included in the comparison whose seedling performance was stable over years. The hypothesis is that examination of the seedling reaction over several years in one location can significantly improve the value of seedling tests.
This problem represents that part of the work on seedling data which is closest to the genetically determined resistance or susceptibility : only then has a comparison of the seedling and head blight reactions any significance.

\section{MATERIALS AND METHODS}

The experiments lasted from 1980 to 1983 including five tests. Details are summarized in Table 1.

As the most important Fusarium species in wheat in Hungary are $F$. graminearum Schwabe and $F$. culmorum (W. G. Smith) Sacc. (MeSTERHÁZY, 1984) we used these species for the testing. The fungus strains were isolated and identified by the author using the BоOTH (1971) manual. 
TABLE 1

Details of the seedling tests with Fusarium graminearum (F.g.) and F. culmorum (F.c.) on wheat in 1980-1983. Tests sur plantules de blé avec Fusarium graminearum (F.g.) et F. culmorum (F.c.) en 1980-1983.

\begin{tabular}{|c|c|c|c|c|c|c|c|c|}
\hline $\begin{array}{l}\text { Experiment } \\
\text { No. }\end{array}$ & $\begin{array}{l}\text { Year of } \\
\text { harvest }\end{array}$ & $\begin{array}{l}\text { Date of } \\
\text { test }\end{array}$ & $\begin{array}{l}\text { No. of } \\
\text { genotypes }\end{array}$ & $\begin{array}{l}\text { No. of } \\
\text { locations }\end{array}$ & Isolate & $\begin{array}{l}\text { Dilution } \\
\text { rate of the } \\
\text { inoculum }\end{array}$ & $\begin{array}{l}\text { Conidium } \\
\text { concentration } \\
\times 10^{6}\end{array}$ & $\begin{array}{l}\text { No. of } \\
\text { replicates }\end{array}$ \\
\hline 1. & 1980 & $\begin{array}{l}\text { Febr. } \\
1981\end{array}$ & 90 & $\begin{array}{l}5 \text { ( } 2 \text { sample series } \\
\text { per location) }\end{array}$ & F.g. 12377 Loc. $\left({ }^{2}\right)$ 1-2 & $1: 4$ & $\begin{array}{c}\text { only } \\
\text { mycelium }\end{array}$ & 3 \\
\hline 2. & 1980 & $\begin{array}{l}\text { April } \\
1981\end{array}$ & 108 & $\begin{array}{l}1 \text { (four sample series } \\
\text { per location) }\end{array}$ & $\begin{array}{l}\text { F.g. } 12377 \mathrm{a}\left({ }^{1}\right) \text { Series } 1-2 \\
\text { F.g. } 12377 \mathrm{~b}\left({ }^{1}\right) \text { Series } 3-4\end{array}$ & $\begin{array}{l}1: 4 \\
1: 4\end{array}$ & $\begin{array}{l}0.19+M\left({ }^{4}\right) \\
0.10+M\end{array}$ & 3 \\
\hline 3. & 1981 & $\begin{array}{c}\text { Jan.-Febr. } \\
1982\end{array}$ & 36 & $\begin{array}{l}9 \text { (1 loc., } 2 \text { sample } \\
\text { series) }\end{array}$ & $\begin{array}{l}\text { F.g. } 12377 \mathrm{a}\left({ }^{1}\right) \text { Loc. } 1-3 \\
\text { F.g. } 12377 \mathrm{~b}\left(^{1}\right) \text { Loc. } 4-10\end{array}$ & $\begin{array}{l}\text { no } \\
\text { no }\end{array}$ & $\begin{array}{l}0.32+\mathrm{M} \\
0.12+\mathrm{M}\end{array}$ & 3 \\
\hline 4. & 1982 & $\begin{array}{l}\text { March-April } \\
1983\end{array}$ & 36 & $\begin{array}{l}10 \text { (1 loc., } 2 \text { sample } \\
\text { series) }\end{array}$ & $\begin{array}{l}\text { F.g. } 12377 \quad \text { 1st repl. }\left({ }^{3}\right) \\
\text { F.c. } 12375 \mathrm{a}\left({ }^{1}\right) \text { 2nd repl. } \\
\text { F.c. } 12375 b\left({ }^{1}\right) \text { 3rd repl. }\end{array}$ & $\begin{array}{l}1: 2 \\
1: 7 \\
1: 8\end{array}$ & $\begin{array}{l}0.12+\mathrm{M} \\
0.19+\mathrm{M} \\
0.12+\mathrm{M}\end{array}$ & 3 \\
\hline 5. & 1983 & $\begin{array}{c}\text { Jan.-Febr. } \\
1984\end{array}$ & 48 & 6 & $\begin{array}{l}\text { F.g. } 12377 \text { a }\left({ }^{1}\right) \text { 1st repl. } \\
\text { F.c. } 12375 \quad \text { 2nd-3rd repl. } \\
\text { F.g. } 12377 \text { b }\left({ }^{1}\right) \text { 4th repl. }\end{array}$ & $\begin{array}{l}1: 1 \\
1: 4 \\
1: 4\end{array}$ & $\begin{array}{l}0.06+\mathrm{M} \\
0.02+\mathrm{M} \\
0.08+\mathrm{M}\end{array}$ & 4 \\
\hline
\end{tabular}

Remarks : $\left({ }^{1}\right)$ a and $b$ mean different inocula of the same isolate $:\left({ }^{2}\right)$ loc. $=$ location $;\left({ }^{3}\right)$ repl. $=$ replication $;\left({ }^{4}\right) \mathbf{M}=$ mycelium is also present.

The inoculum was prepared by the bubble breeding method (MESTERHÁZY, 1977), which is suitable for providing 10-20 1 uniform inoculum for artificial inoculation. For this, liquid Czapek-Dok medium was used in $10 \mathrm{l}$ glass balloons sterilized in an autoclave at 1.5 bar for $1.5-2 \mathrm{~h}$. Sterilized air supplied the necessary oxygen. The inoculum is ready in 5-8 days at room temperature.

As mycelium infects as well as conidia (TAKEGAMI \& SASAI, 1970), and in this type of inoculum different amounts of mycelium are produced, the conidium concentration is not alone suitable to regulate pathogenicity. In addition, the same isolate may produce inocula with different pathogenicity and there are also genetical differences between strains regarding pathogenicity (MESTERHÁZY, 1978b, 1981). Therefore we tested pathogenicity at the original concentration and at $1: 1,1: 2$ and $1: 4$, and in the case of very high pathogenicity $1: 8$ dilutions. For this a resistant "74-2 » and a susceptible « Bzt-1 " genotype was used. In this way we could avoid the use of inoculum with too high and too low pathogenicity.

We found that the Petri dish test results showed closer correlation with the head blight test than the greenhouse tests (MESTERHAZY, 1984b), and we therefore used the Petri dish test (MesterhäZ, 1978b). A double layer of filter paper (FILTRAK-6) was placed in the dishes (12 cm diameter), carrying the inoculum. In 1980 the filter paper was dipped in the suspension and then placed in the dish. However, by this method, one third of the suspension had to be discarded because of increasing inoculum concentration. Since 1982 we have used an Oxford Macro Set pipette $(10 \mathrm{ml} /$ Petri dish) so the inoculum concentration can be kept stable during the infestation of several hundred dishes. After every 30 Petri dishes the two check varieties were inserted to control any possible change in pathogenicity.

In a dish 25 healthy seeds were sown, embryos upwards. The number of germinated seeds was counted on the 2nd day, and the number of healthy seedlings was then scored daily. Their mean related to the uninoculated control gave the relative germination rate. The dishes were stored during the test in a dark thermostat at $25{ }^{\circ} \mathrm{C}$. The number of replicates was 3-4 (see table 1).

The seed samples originated from variety testing experiments in different locations. We received an average sample from four field plots of every variety at every location. They were collected after harvest and stored at room temperature until the test.

To evaluate data variance, correlation and principal component analyses (VOPP Statistik Program without rotation on $\mathrm{R}-40$ computer) were used.

\section{RESULTS}

In 1980 the 90 varieties differed significantly from each other. The most resistant genotypes reached about $50 \%$ of the control, the best mean values from the 10 sites were 54.0, 49.9, 44.8, 55.9, 49.6 and $45.58 \%$. The lowest values were $15.74,19.96$ and $21.10 \%$. The overall average of the experiment was $33.92 \%$. The LSD value at $P=5 \%$ was only 3.92 , less than $10 \%$ of the range of variation. The variance analysis (table 2) shows that not only the main effects but also the interactions were highly significant. Here the variety by location interaction is important showing the different ranks in different locations, but we have to consider also the significance of variety by location and location by seed sample series interactions, too. The correlations reflect the same phenomenon (table 3), the performance on different sites being between 0.34-0.44 ( $\mathrm{P}=0.1 \%)$, but the two series from Fülöpszállás (irrigated and dry cultivated) showed $r=0.83$. The individual series gave $r=0.66$ $0.82(\mathrm{P}=0.1 \%)$ with the average performance at the five locations. 
TABLE 2

Performance of 90 winter wheat genotypes from five locations (2 seed sample series per location)

to Fusarium graminearum seedling blight in 1980. Variance analysis.

Performances de 90 génotypes de blé d'hiver provenant de cinq localités (2 séries d'échantillons de semences par localité), vis-à-vis de Fusarium graminearum, au stade plantule, en 1980. Analyse de variance.

\begin{tabular}{|c|c|c|c|c|c|}
\hline Source of variance & SS & DF & MS & F & $\mathrm{F}_{\mathrm{A} \times \mathrm{B} \times \mathrm{C}}$ \\
\hline Genotype (A) & 186704.34 & 89 & 2097.80 & $42.76^{+++}$ & $7.56^{+++}$ \\
\hline Location (B) & 43178.93 & 4 & 10794.73 & $220.05^{+++}$ & $38.97^{+++}$ \\
\hline Sample series $(\mathrm{C})$ & 1876.54 & 1 & 1876.54 & $38.25^{+++}$ & $6.77^{+++}$ \\
\hline$A \times B$ & 149059.41 & 356 & 418.71 & $8.54^{+++}$ & $1.51^{+++}$ \\
\hline$A \times C$ & 18288.37 & 89 & 205.49 & $4.19^{+++}$ & 0.74 \\
\hline $\mathrm{B} \times \mathrm{C}$ & 4315.71 & 4 & 1078.93 & $21.99^{+++}$ & $3.89^{++}$ \\
\hline$A \times B \times C$ & 98605.32 & 356 & 276.89 & $5.65^{+++}$ & \\
\hline Error & 88300.97 & 1800 & 49.06 & & \\
\hline Total & 586013.88 & 2699 & & & \\
\hline
\end{tabular}

$+++\mathrm{P}=0.1 \% ;{ }^{++} \mathrm{P}=1 \%$

TABLE 3

Correlations between performance, against F. graminearum, of genotypes from five locations at the seedling stage in $1980\left({ }^{1}\right)$. No. of entries 90 . Corrélations entre les performances au stade plantule de 90 génotypes provenant de 5 localités, vis-à-vis de F. graminearum en 1980.

\begin{tabular}{|c|c|c|c|c|c|c|}
\hline \multirow[t]{2}{*}{ Location } & \multirow{2}{*}{$\begin{array}{c}\text { Táplánszentkereszt } \\
1\end{array}$} & \multicolumn{2}{|c|}{ Fülöpszállás } & \multirow{2}{*}{$\begin{array}{c}\text { Szeged } \\
4\end{array}$} & \multirow{2}{*}{$\begin{array}{c}\text { Kecskemét } \\
5\end{array}$} & \multirow{2}{*}{$\begin{array}{c}\text { Mean } \\
6\end{array}$} \\
\hline & & $\underset{2}{\text { Irrigated }}$ & $\begin{array}{c}\text { Not irrigated } \\
3\end{array}$ & & & \\
\hline 1 & - & $0.34^{+++}$ & $0.36^{+++}$ & $0.39^{+++}$ & $0.37^{+++}$ & $0.72^{+++}$ \\
\hline 2 & - & - & $0.83^{+++}$ & $0.44^{+++}$ & $0.41^{+++}$ & $0.82^{+++}$ \\
\hline 3 & - & - & - & $0.40^{+++}$ & $0.41^{+++}$ & $0.81^{+++}$ \\
\hline 4 & - & - & - & - & $0.39^{+++}$ & $0.66^{+++}$ \\
\hline 5 & - & - & - & - & - & $0.66^{+++}$ \\
\hline
\end{tabular}

$+++\mathbf{P}=0.1 \%$.

(1) The matrix was calculated with the means of the two samples per location.

TABLE 4

Performance of 108 winter wheat genotypes against F. graminearum seedling blight. 1 location, four sample series. 1980. Variance analysis. Performances de 108 génotypes de blé d'hiver au stade plantule vis-à-vis de $\mathrm{F}$. graminearum. 1 localité, 4 séries d'échantillons, 1980. Analyse de variance.

\begin{tabular}{lrrrrr}
\hline \multicolumn{1}{c}{ Source of variance } & SS & DF & MS & F & F \\
\hline Genotype (A) & 37200.75 & 107 & 347.67 & $7.96^{+++}$ \\
Sample series (B) & 64740.49 & 3 & 21580.16 & $494.16^{+++}$ & $192.68^{++++}$ \\
A $\times$B & 35952.93 & 321 & 112.00 & $2.56^{+++}$ & \\
Error & 37727.79 & 884 & 43.67 & \\
Total & 175621.96 & 1295 & & \\
\hline \hline
\end{tabular}

$++P=0.1 \%$.

In the second experiment of this year, 107 varieties were tested. According to the variance analysis a similar situation was obtained (table 4), but the correlation matrix showed larger deviations (table 5). Here the first three data series correlated above $r=0.40$, but the fourth series differed largely from the first three, giving significantly lower coefficients.

The relationships between the reaction at individual sites and the mean were highly significant, above $r=0.67(P=0.1 \%)$; the variety differences were highly significant, the best genotypes reached $30 \%$ of the control, the worst were below $10 \%$, LSD on $5 \%$ was $5.29 \%$.

In 1981, 36 genotypes were tested from 10 locations. There were significant variety and location effects and
TABLE 5

Correlations between the reactions to $\mathrm{F}$. graminearum of the four sample series of 108 genotypes at the seedling stage in 1980.

Corrélations entre les réactions au stade plantule de 108 génotypes de blé d'hiver vis-à-vis de $\mathrm{F}$. graminearum, 4 séries d'échantillons, en 1980.

\begin{tabular}{cccccc}
\hline Sample serie & 1 & 2 & 3 & 4 & Mean \\
\hline 1 & - & $0.56^{+++}$ & $0.43^{+++}$ & 0.18 & $0.71^{+++}$ \\
2 & - & - & $0.46^{+++}$ & $0.27^{++}$ & $0.75^{+++}$ \\
3 & - & - & - & $0.45^{+++}$ & $0.79^{+++}$ \\
4 & - & - & - & - & $0.67^{+++}$ \\
\hline
\end{tabular}

$+++P=0.1 \% ;++P=1 \%$. 
their interaction was also significant (table 6). The maximum values of varieties were about 50 , the worst numbers being about $25 \%$ of the control. The correlations (table 7) varied largely, from no significance to $\mathrm{r}=0.74(\mathrm{P}=0,1 \%)$; every possibility was represented. It is worth mentioning that the results on sites 3 and 7 generally showed very poor or no significant relationship with the data of the other locations. We do not know the basis of this finding. We cannot decide whether an unknown methodical problem or some special environmental effect, eventually another disease is responsible for this.

Another problem arises from the fact that the two Fülöpszállás series showed no relationship this year, as they did in the last year. As the seed samples from the first three and the remaining seven were treated by different inocula of the same isolate, the performance within groups at locations 3 and 7 could be compared.
In the first case the differences range from $14.76 \%$ at Táplánszentkereszt to $53 \%$ at Szeged-Ságvári Station, in the second group from $24.02 \%$ in Paks to $47.33 \%$ in Edelény, as percentages of the control. The LSD for sites was 2.86 at $5 \%$ and 4.81 at $P=0.1 \%$, i.e. the location effect was highly significant.

In 1982, 36 genotypes were investigated; the data are presented in Table 8 . The variety differences were highly significant (from $14.8 \%$ to $30.8 \%$ of the control, mean $22.5 \%$, LSD $5 \% 4.16 \%$ ), and this was valid for the locations also (from $15.6 \%$ to $31.4 \%$ of the control, mean is $22.5 \%$, LSD $5 \%=2.3 \%$ ). The interaction between them was also significant at $\mathrm{P}=0.1 \%$. This is not a surprise after the results presented for previous years. The isolate effect was highly significant; in the analysis it is the replicate effect, as the different replicates were tested with different isolates. The correlations gave relation-

TABLE 6

Reaction of 36 winter wheat genotypes from 10 location to $\mathrm{F}$. graminearum in seedling tests in 1981. Variance analysis. Réaction de 36 génotypes de blé d'hiver provenant de 10 localités, vis-à-vis de F. graminearum, au stade plantule en 1981. Analyse de variance.

\begin{tabular}{|c|c|c|c|c|c|}
\hline Source of variance & SS & DF & MS & $\mathrm{F}$ & $\mathrm{F}_{\mathrm{A} \times \mathrm{B}}$ \\
\hline Genotype (A) & 38492.69 & 35 & 1099.79 & $9.60^{+++}$ & $6.45^{t+t}$ \\
\hline Location (B) & 208070.68 & 9 & 23118.96 & $201.72^{+++}$ & $135.76^{+++}$ \\
\hline$A \times B$ & 53641.54 & 315 & 170.29 & $1.49^{+++}$ & \\
\hline Error & 82290.10 & 718 & 114.61 & & \\
\hline Total & 390354.82 & 1079 & & & \\
\hline
\end{tabular}

$++\mathrm{P}=0.1 \%$

TABLE 7

Correlations between reactions of 36 wheat genotypes to F. graminearum seedling blight at ten locations in 1981. Corrélations entre les réactions au stade plantule de 36 génotypes de blé vis-à-vis de F. graminearum en 10 localités, en 1981.

\begin{tabular}{|c|c|c|c|c|c|c|c|c|c|c|}
\hline Location & 1 & 2 & 3 & 4 & 5 & 6 & 7 & 8 & 9 & 10 \\
\hline 1 & - & $0.42^{+++}$ & 0.25 & $0.74^{+++t}$ & 0.29 & $0.41^{++}$ & -0.02 & $0.40^{++}$ & $0.59^{++++}$ & 0.26 \\
\hline 2 & - & - & 0.32 & 0.30 & $0.64^{++++}$ & $0.43^{+++}$ & 0.07 & $0.32^{+}$ & $0.48^{+++}$ & $0.41^{++}$ \\
\hline 3 & - & - & - & $0.39^{++}$ & $0.39^{++}$ & -0.22 & 0.13 & 0.19 & 0.30 & 0.29 \\
\hline 4 & - & - & - & - & $0.40^{++}$ & $0.52^{++++}$ & 0.16 & $0.53^{++++}$ & $0.57^{++++}$ & 0.18 \\
\hline 5 & - & - & - & - & - & $0.59^{++++}$ & 0.26 & $0.35^{+}$ & $0.41^{++}$ & $0.47^{+++}$ \\
\hline 6 & - & - & - & - & - & - & 0.27 & $0.43^{+++}$ & $0.53^{+++t}$ & $0.51+++$ \\
\hline 7 & - & - & - & - & - & - & - & 0.17 & 0.32 & 0.31 \\
\hline 8 & - & - & - & - & - & - & - & - & $0.36^{++}$ & 0.28 \\
\hline 9 & - & - & - & - & - & - & - & - & - & $0.41^{++}$ \\
\hline
\end{tabular}

${ }^{++}+{ }^{+} \mathrm{P}=0.1 \% ;{ }^{++}{ }^{+} \mathrm{P}=1 \%{ }^{++} \mathrm{P}=2 \% ;{ }^{+} \mathrm{P}=5 \%$

TABL.E 8

Performance of 36 winter wheat varieties against F. graminearum and F. culmorum at the seedling stage; seed samples from ten locations in 1982. Variance analysis.

Performances de 36 variétés de blé d'hiver vis-à-vis de F. graminearum et de F. culmorum au stade plantule, provenant d'échantillons de semences de 10 localités, en 1982. Analyse de variance.

\begin{tabular}{|c|c|c|c|c|c|}
\hline & & & & & \\
\hline Genotype (A) & 21220.44 & 35 & 606.29 & $8.12^{+++}$ & $5.09^{+++}$ \\
\hline Location (B) & 23562.31 & $10\left(^{1}\right)$ & 2356.23 & $31.55^{+++}$ & $19.81^{t++}$ \\
\hline $\mathrm{A} \times \mathrm{B}$ & 41631.90 & 350 & 118.94 & $1.59^{+++}$ & \\
\hline Replication & 17951.64 & 2 & & & \\
\hline Error & 58911.79 & 789 & 74.66 & & \\
\hline Total & 163278.08 & 1187 & & & \\
\hline
\end{tabular}

$++\mathrm{P}=0.1 \%$.

(') From one location two sample series were tested, therefore is the No. of tested series 11. 
TABLE 9

Correlations between reactions of 36 wheat genotypes to Fusarium seedling blight from ten locations (11 sample series) in 1982. Corrélations entre les réactions au stade plantule de 36 génotypes de blé vis-à-vis de Fusarium graminearum en 10 localités (11 séries d'échantillons) en 1982.

\begin{tabular}{|c|c|c|c|c|c|c|c|c|c|c|c|}
\hline $\begin{array}{l}\text { Loca- } \\
\text { tions }\end{array}$ & 2 & 3 & 4 & 5 & 6 & 7 & 8 & 9 & 10 & 11 & Mean \\
\hline 1 & $0.38^{+}$ & 0.31 & $0.39^{++}$ & $0.41^{++}$ & $0.42^{++}$ & $0.49^{+++}$ & $0.34^{+}$ & 0.21 & $0.40^{++}$ & 0.31 & $0.73^{++++}$ \\
\hline 2 & - & 0.27 & $0.39^{++}$ & 0.21 & 0.25 & 0.15 & 0.13 & $0.43^{++}$ & 0.04 & 0.27 & $0.54^{++++}$ \\
\hline 3 & - & - & 0.07 & $0.51^{+++}$ & 0.22 & 0.21 & 0.10 & 0.29 & $0.38^{++}$ & 0.24 & $0.57^{++++}$ \\
\hline 4 & - & - & - & 0.09 & 0.13 & $0.54^{++++}$ & $0.46^{+++}$ & 0.20 & $0.37^{++}$ & $0.47^{+++}$ & $0.64^{++++}$ \\
\hline 5 & - & - & - & - & 0.27 & 0.23 & 0.00 & 0.23 & $0.42^{++}$ & 0.07 & $0.53^{++++}$ \\
\hline 6 & - & - & - & - & - & 0.13 & 0.25 & 0.21 & 0.32 & $0.35^{+}$ & $0.55^{++++}$ \\
\hline 7 & - & - & - & - & - & - & $0.37^{+}$ & -0.05 & $0.51^{+++}$ & 0.32 & $0.62^{++++}$ \\
\hline 8 & - & - & - & - & - & - & - & 0.19 & $0.48^{++}+$ & $0.56^{++t+}$ & $0.59^{++++}$ \\
\hline 9 & - & - & - & - & - & - & - & - & -0.06 & $0.43^{++}$ & $0.43^{++}$ \\
\hline 10 & - & - & - & - & - & - & - & - & - & 0.28 & $0.65^{++++}$ \\
\hline 11 & - & - & - & - & - & - & - & - & - & - & $0.63^{++++}$ \\
\hline
\end{tabular}

$+++{ }^{+} \mathrm{P}=0.1 \% ;{ }^{+{ }^{+}+} \mathrm{P}=1 \% ;{ }^{++} \mathrm{P}=2 \% ;{ }^{+} \mathrm{P}=5 \%$

TABLE 10

Performance of 48 wheat genotypes from six locations against Fusarium seedling blight in 1983.

Performances de 48 génotypes de blé au stade plantule, vis-à-vis de la fusariose, en provenance de 6 localités en 1983.

\begin{tabular}{|c|c|c|c|c|c|c|}
\hline Location & 2 & 3 & 4 & 5 & 6 & Mean \\
\hline 1 & $0.44^{++}$ & $0.55^{+++}$ & $0.39^{++}$ & $0.44^{++}$ & $0.60^{+++}$ & $0.74^{+++}$ \\
\hline 2 & - & $0.53^{+++}$ & $0.45^{++}$ & $0.55^{+++}$ & $0.54^{+++}$ & $0.76^{+++}$ \\
\hline 3 & - & - & $0.44^{++}$ & $0.59^{+++}$ & $0.70^{+++}$ & $0.84^{+++}$ \\
\hline 4 & - & - & - & $0.30^{+}$ & $0.45^{++}$ & $0.65^{+++}$ \\
\hline 5 & - & - & - & - & $0.68^{+++}$ & $0.77^{+++}$ \\
\hline 6 & - & - & - & - & - & $0.85^{+++}$ \\
\hline
\end{tabular}

$+{ }^{++} \mathrm{P}=0.1 \% ;{ }^{++} \mathrm{P}=1 \% ;{ }^{+} \mathrm{P}=5 \%$

Variance analysis.

\begin{tabular}{lrrrr}
\hline & Source of variance & SS & DF & MS \\
\hline Genotype (A) & 43303.33 & 47 & 921.35 \\
Location (B) & 14419.10 & 5 & $11.22^{+++}$ & 2883.82 \\
A $\times$ B & 52219.90 & 235 & $35.11^{+++}$ & $13.23^{++++}$ \\
Replication & 87279.75 & 3 & $2.65^{+++}$ \\
Error & 70720.25 & 861 & 82.14 \\
Total & 266942.33 & 1151 & \\
\hline
\end{tabular}

ships from no significance to high significance (table 9).

In 1983, 48 genotypes were tested from six locations. The results (table 10) show that the varieties again differed highly significantly (from $19.6 \%$ to $47.5 \%$ of the control, mean $30.6 \%$, LSD $5 \%$ $8.6 \%$ ). This was valid also for the locations (from $25.41 \%$ to $36.4 \%$ of the control, mean $30.6 \%$, LSD $5 \%=3.1 \%$ ) and the interactions were also significant. The effect of different isolates (replicate) was as large as in 1982. The correlations between reactions in different locations are the closest we found during this experimental series. No non-significant relationships was recorded, most of the relations being significant at $\mathrm{P}=0.1 \%$ and mostly with $\mathrm{r}$ over 0.50 .

Principal component analysis was also done in this year (fig. 1). The locations were grouped in two distinct clusters. It seems, however, that the classification was not stable, as the two Kiszombor sample series were classified in different clusters. This was almost the same for the two series from Ságvári Station, where one series was protected against leaf diseases, but the other not. Analyses were also made for the data of years 1981 and 1983, respectively. The picture was different from year to year. In 1981, locations 1,4 and $7,10,11$ as well as 6,8 and 9 produced clusters. In 1982 the locations were grouped in two distinct clusters $(2,3,5,6,9$ and $13 ; 4,7,8,10$ and 11 , and 1 alone) (fig. 1). It is remarkable however that the two series from Kiszombor (loc. 8 and 13) and Ságvári stations ( 1 and 2) were divided separately into the two clusters. In 1983 locations 6, 7, 8 and 9 produced a cluster and location 5 and 11 were distinct from this group. The locations do not produce stable groups. The only location pair which remained in the same group in all three years was 6 and 9 .

As the investigations were based on experiments run for breeding purposes, the material in different experiments was largely divergent. In the tests in 1981 and 1982 only 9 were identical. Their mean reactions 


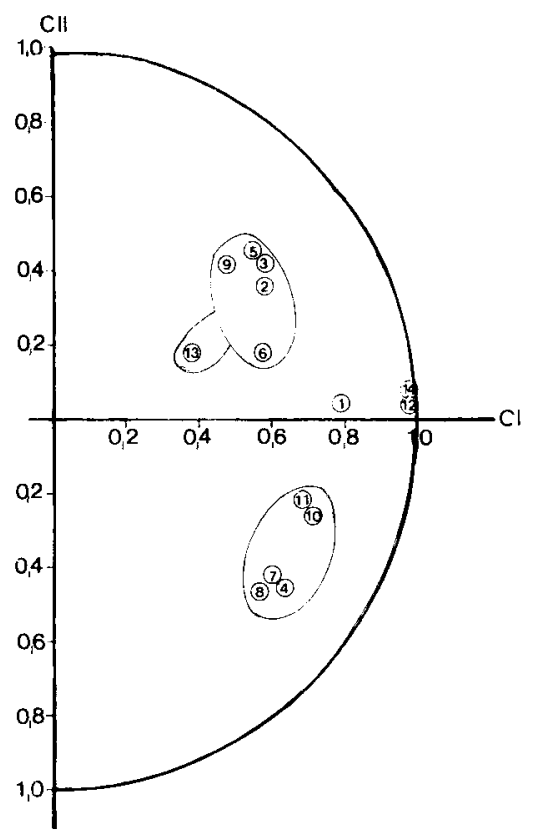

Figure 1

Principal component analysis of the Fusarium seedling test in wheat in 1982. The locations with similar performance are grouped in one cluster. 1 = Ságvári telep, Ist series; $2=$ Ságvári telep, 2nd series; treated with Bayleton; $3=$ Tótkomlós; $4=$ Táplánszentkereszt ; $5=$ Kálló ; $6=$ Paks; $7=$ Makó ; $8=$ Kiszombor, 1 st series $; 9=$ Edelény $; 10=$ Kunszállás $; 11=$ Rákóczifalva $; 12=$ mean for $1-11$ locations $; 13=$ Kiszombor, 2 nd series $; 14=$ mean for $1-11+13$ locations.

Analyse en composantes principales du test sur plantules de blé vis$\grave{a}$-vis de la fusariose en 1982. Les localités ayant des performances semblables sont regroupées.

correlated with $\mathrm{r}=0.677$ at $\mathrm{P}=5 \%$. In 1982-1983, 10 genotypes were identical, the relationship was $\mathrm{r}=0.6508, \mathrm{P}=5 \%$.

\section{DISCUSSION}

The variance analyses show that significant variety differences were detected in every test. The level of significance was always at $P=0.1 \%$. Comparison of genotypes at different locations showed that the ranking order for resistance remained more or less similar. This was valid also for the comparison of the results in different years. Thus, means characterize a variety better than data from individual locations and mean seedling resistance data reflect real genetical differences. The data show that about 6 locations are sufficient when the experiments are as good as they were in 1983.

The location differences were highly significant in every test. In the first three tests, as mentioned, different inocula were applied for different series or groups of locations. Therefore the differences between groups of locations include here also pathogenicity differences. In 1982 and 1983, for the first time, the data reflect purely location differences, as here the same inocula were used for every seed sample. The high differences previously shown for groups of locations only proved valid here for all locations.

However, the location differences also have a more theoretical significance. The point is the predisposition. Literature on this was recently summarized in two excellent review articles (COLHOUN, 1979;
YARWOOD, 1976). Many important factors were detailed about the effects of environmental factors. However, data were not found concerning environmental effects on the predisposition of the next seedling generation. As this effect is highly significant, this fact should be considered in seedling tests not only in the wheat-Fusarium system, but in many other host-pathogen relationships where seedling tests have and may have an importance. This finding explains further some of the negative results in the seedling adult stage resistance comparisons, too. The question is whether the location effect is stable or not. Comparing the data from 1981, 1982 and 1983, we find that it is not. The PCAs also showed this fact. So changing environmental effects also have their role and there is no real possibility of selecting a good area and regularly producing there material with an excellent predisposition. May be a more detailed study on vigor may also give new insights in this problematic field beyond our present knowledge. The background of the location effect is not clear. Certainly, differences in soil structure, level of fertilizers, precipitation, husbandry, etc. may cause such differences, but we are not yet in the position to identify exactly the factors responsible. It seems now from investigation of uninoculated controls that differences in health condition (seed mycoflora) play only a minor role, as there was no significant difference in this respect between the samples from different locations.

How should we estimate the significance of the location by genotype interaction ? In effect, the interaction $(\mathrm{A} \times \mathrm{B}$, or $\mathrm{A} \times \mathrm{B} \times \mathrm{C})$ always differed significantly from the main effects (genotype or location), i. e. the variance of the interaction represented a relatively small part of the total variance (tables 2, 4, 6, 8 and 10). The situation is similar to what we see in breeding programs for yield performance; in spite of the fact of differences in performance and ranks in different locations, selection for high yielding ability is possible, and here performance trials at many locations make a significant contribution. The correlations show that there is a tendency for similar performance of individual genotypes at different locations. We conclude therefore, that there is a theoretical possibility of breeding genotypes with high seedling resistance. We think that the results allow the conclusion that average performance at different locations gives a better reflection of genetically founded seedling resistance. This is important for us because a comparison of seedling and head blight resistance has meaning only if the data reflect genetically meaningful reactions. If a positive answer on the seedling head blight connection would be the result, the value of the seedling tests would be high. In the opposite case, the seedling resistance would have only marginal importance for practical breeding work for resistance.

Reçu le 17 juillet 1984 Accepté le 23 janvier 1985.

\section{ACKNOWLEDGEMENTS}

The author wishes to express his thanks to laboratory assistants Dr. Irma MozsiK and Ilona PuszTaI for their work during the experiments, Dr. László PARÁDI and Dr. Zoltán Barabás for the seed samples and Dr. Maria DévénYI for the PC analysis. 


\section{REFERENCES}

Booth C., 1971. The genus Fusarium. Comm. Mycol. Inst., Kew, Surrey, England, 237 p.

Colhoun J., 1979. Predisposition by the environment, 75-96. In : Horsfall, J. G. \& E. B. Cowling " Plant disease an advanced treatise ", Vol. 4, $466 \mathrm{p}$.

Mesterházy Á., 1977. Reaction of winter wheat varieties to four Fusarium species. Phytopathol. Z., 90, 104-112.

Mesterházy Á., 1978a. Gabonafélék ellenállósága a Fusarium genus néhány fajával szemben (Resistance of cereals to Fusarium spp.). Dissertation for candidate of sciences, Szeged, $117 \mathrm{p}$.

Mesterházy Á., 1978b. Comparative analysis of artificial inoculation methods with Fusarium spp. on winter wheat varieties. Phytopathol. Z., 93, 12-25.

Mesterházy Á., 1981. The role of aggressiveness of Fusarium graminearum in the inoculation tests on wheat in seedling state. Acta Phytopathol. Acad. Sci. Hung., 16, 282-292.
Mesterházy Á., 1983. Breeding wheat for resistance to Fusarium graminearum and F. culmorum. Z. Pflanzenzücht., 91, 295-311.

Mesterházy Á., 1948a. Fusarium species of wheat in South Hungary, 1970-1983. Cereal Res. Comm., 12, 167-170.

Mesterházy Á., 1984b. A laboratory method to predict pathogenicity of tusarium graminearum in field and resistance to scab. Acta Phytopathol. Acad. Sci. Hung., 19, (in press).

Takegami S., Sasai K., 1970. Investigations on the resistance of wheat varieties to Gibberella zeae after particular inoculation techniques. X. Experiments on improved inoculation methods involving conidiophores and hyphae. Proc. Crop Sci. Soc. Jap., 39, 1-6. Yarwood C. E., 1976. Modification of the host response-predisposition, 703-718. In : Heitefuss, R. \& Williams, P. H. "Physiological plant pathology », Springer Verlag Berlin, Heidelberg, New York, $890 \mathrm{p}$. 